\title{
AMAZÔNIA: DA CRISE À INTEGRAÇÃO ATÍPICA E TRUNCADA
}

\author{
AMAZONIA: FROM CRISIS TO AN ATYPICAL \\ TRUNCATED INTEGRATION
}

\author{
Wilson Cano \\ Universidade Estadual de Campinas, São Paulo, Brasil, <wcano@eco.unicamp.br>
}

Resumo. O artigo mostra que, entre 1930 e 1980 a região $^{1}$ se beneficiou das políticas econômicas federais, em especial das de desenvolvimento e integração do mercado nacional, a chamada desconcentração virtuosa. Contudo, a partir da crise dos anos 80 o Estado se debilitou fiscal e financeiramente, e, com a adoção das políticas neoliberais a partir de 1989-1990, essa deterioração ficou ainda maior, com uma perversa política macroeconômica (abertura desregrada, juros elevados, câmbio valorizado, e outros) divorciada da idéia de desenvolvimento nacional e regional. Graças ao neoliberalismo e à guerra fiscal, a desconcentração que ocorre neste segundo período se torna espúria, truncando e tornando atípica a integração produtiva da região com o restante da nação. A periodização adotada será: pré 1960; 1970's; 1980-1989; 1989-2003, e 2003-2010.

Palavras-chave: desenvolvimento regional; industrialização; guerra fiscal; neoliberalismo.

Abstract. This paper shows that, between 1930 and 1980 the region has benefited from the federal economic policies, especially the development and integration of the domestic market, the so-called virtuous deconcentration. However, since the crisis of the 80 's and the government's tax and financial slump, as well as the adoption of neoliberal policies from 1989 to 1990, this deterioration was even greater, with a perverse macroeconomic policy (unregulated opening, high interest rates, overvalued exchange rate, and others) and divorced from the idea of national and regional development. Thanks to neoliberalism and tax war, deconcentration that occurs in the second period becomes spurious, making the Amazon's productive integration with the rest of the nation rather atypical and truncated. The adopted periodization is: pre 1960; 1970's; 1980-1989; 1989-2003, and 2003-2010.

${ }^{1}$ A região Norte do Brasil perfaz cerca $42 \%$ do território nacional é se compõe das seguintes unidades federadas: Acre, Amapá, Amazonas, Pará, Rondônia, Roraima e Tocantins. A Amazônia, além de abarcar a região Norte, abrange ainda pequenas frações das regiões Centro-Oeste e Nordeste. A economia da borracha, no período contemplado neste texto, restringiu-se basicamente aos estados do Acre, Amazonas e Pará. Dados e cifras apresentados no texto se referem a alguns estados ou ao Norte como um todo.

Am. Lat. Hist. Econ., año 20, núm. 2, mayo-agosto, 2013, pp. 67-95 
Key words: regional development, industrialization, tax war, neoliberalism.

Fecha de recepción: julio de 2012. Fecha de aceptación: octubre de 2012.

\section{INTRODUÇÃO}

s dificuldades para obter dados e informações sobre a economia
da região Norte, anteriores ao final da década de 1960 e a própria
evolução e transformação dessa economia, no período posterior àquele, recomendam uma reflexão mais sintética para o primeiro deles. Dessa forma, dividirei o texto em duas partes, a primeira correspondente a um período (ainda mais longo) que se estende até meados dos anos de 1960 e a segunda, ao período subseqüente. Para a primeira parte, usarei largamente, além das fontes citadas, alguns textos anteriores que escrevi. ${ }^{2}$

\section{A CÉlula EXPORTADORA REGIONAL DO NORTE: AUGE, DECLÍNIO E INÍCIO DA INTEGRAÇÃO NACIONAL}

Excluída a parte amazônica da economia maranhense, a região Norte manteve-se, até meados do século XIX, na atividade extrativista-florestal, ligando-se precariamente ao comércio internacional. A atividade extratora da borracha expandiu-se lentamente nas décadas de 1860 e de 1870, atingindo, na seguinte, um período mais expressivo, chegando ao auge, entre 1890 e 1912. Essa expansão foi induzida pela subida de seus preços externos, que triplicam entre 1880 e 1910, situando-se, na média do período de 1911-1920, a nível 60\% mais alto do que os preços médios vigentes no período de $1881-1890 .^{3}$

No sentido de poder avaliar qualitativamente o potencial econômico dessa atividade, comparo-a com a expansão cafeeira em São Paulo, no período de 1870 a 1920 . Vejamos o confronto das exportações paulistas de café e das de borracha pela Amazônia, assim como o de suas respectivas populações (ver tabela 1).

Acrescente-se, ainda, que, no mesmo período, o fluxo imigratório para a Amazônia equivaleu a 38.5\% do recebido por São Paulo. ${ }^{4}$ Somadas as exportações desse meio século, as de borracha equivaleram, aproxima-

\footnotetext{
${ }^{2}$ Cano, Raízes, 2007, cap. 1, item 1.2.1, pp. 95-99, e Desequilibrios, 2007, caps. 3 e 5.

${ }^{3}$ Sobre as linhas gerais da evolução da economia da borracha, Furtado, Formação, 1961, cap. 23.

${ }^{4}$ Essa porcentagem é calculada com base nas quantificações efetuadas, para São Paulo, por Camargo, "Crescimento", 1953, e, para a Amazônia, Furtado, Formação, 1961, cap. 23.
} 
TABELA 1. ESTADO DE SÃO PAULO

E AMAZÔNIA EXPORTAÇÕES DE CAFÉ

E DE BORRACHA E RELAÇÃO POPULACIONAL

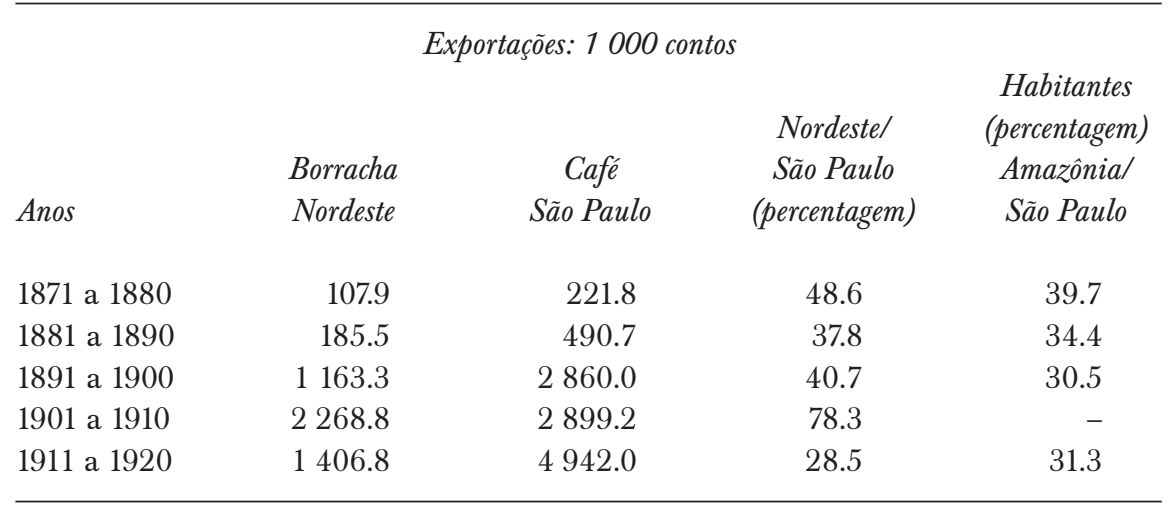

Fontes: Anuário, 1939-1940, e Fraga, "Resenha”, 1963, S. Paulo; para a população, censos demográficos de 1872, 1890, 1900 e 1920, em Cano, Raizes, 2007.

damente, a 45\% das exportações paulistas de café. Dados esses fatos, poderse-ia perguntar por que razões a Amazônia não conseguiu transformar essa fonte primária de "energia" econômica que foi a borracha, gerando um "complexo econômico" tão dinâmico quanto foi o cafeeiro, guardadas as devidas proporções de ambos. Não parece difícil responder a essa indagação.

Em primeiro lugar, o problema maior parece ter residido na forma principal em que se desenvolveram as relações de produção na economia da Amazônia, ou seja, na preponderância do aviamento. ${ }^{5}$ Consistia esse sistema numa cadeia de agentes, cujo primeiro elo (o maior e mais poderoso) era representado pelas grandes casas exportadoras (e, naturalmente, também importadoras) que concedem crédito (aviam) a intermediários menores, emprestando-lhes dinheiro e adiantando meios de subsistência e bens de produção, os rudimentares instrumentos auxiliares da produção da borracha. ${ }^{6}$ Os médios e pequenos intermediários, por sua vez, "repassavam" o crédito recebido (e, portanto, eram ao mesmo tempo aviados $e$

\footnotetext{
${ }^{5}$ Para o tema sobre o aviamento ver o clássico trabalho de Santos, "Equilíbrio", 1968, e Sampaio, "Trabalho", 2002.

${ }^{6}$ Como o próprio autor citado na nota anterior mostra, é evidente que à medida que o sistema bancário se desenvolve e penetra mais no interior da Amazônia, o sistema de aviamento é enfraquecido; ainda hoje, subsistem seus resquícios tanto na atividade extrativa da borracha como na da produção de juta.
} 
aviadores) aos últimos elos dessa cadeia, que eram os produtores diretos da atividade extrativa. Estes últimos constituíam genuinamente os aviados.

Esse fluxo de crédito, cuja componente monetária era pequena, predominando a fração em espécie, tinha como contra partida outro fluxo em espécie (a borracha e, mais tarde, também a juta), que era contabilizado a preços estabelecidos pelo primeiro elo da cadeia. ${ }^{7}$ Esse fluxo compreendia as seguintes parcelas: o valor dos bens de produção utilizados, o custo de subsistência do produtor direto e os juros e lucros da cadeia de intermediação. A diferença contábil de ajuste nos dois fluxos era o saldo do produtor, devedor na maioria das vezes, o que o tornava ainda mais dependente ao sistema de aviamentos. Quando credor representava, no entanto, parcela insignificante.

Tratava-se, portanto, de um sistema em que cabia ao "comprador" determinar ao produtor independente o preço de produção, provendo-o ainda dos meios de subsistência, a preços da mesma maneira estabelecidos, fixando a "renda" do produtor ao nível de subsistência física. Em suma, a economia da borracha estava organizada em torno do pequeno produtor independente, que era dominado e explorado pelo capital comercial.

Examinemos as raízes da baixa diferenciação da economia da borracha. Em primeiro lugar, é necessário lembrar que, devido à existência de ampla rede fluvial, não se requereram maiores investimentos para a implantação de sistema de transportes. Tais inversões restringiram-se à construção de portos e a oficinas de reparos de embarcações.

Por outro lado, não se estabeleceram as condições mínimas requeridas para o surgimento de uma agricultura mercantil de alimentos. Não, naturalmente, porque inexistisse demanda, que foi atendida por importações de alimentos em volumes apreciáveis. Ao contrário, foi o modo de organização da atividade extrativa, fundada no pequeno produtor independente internado e disperso na floresta virgem, que bloqueou, obviamente, seu nascimento. Quer dizer, nem há, como no café, uma empresa agrícola onde a atividade primária se desenvolve sob o comando do capital nem, muito menos, disponibilidade de terras abertas pela atividade exportadora em que a produção de alimentos pudesse ser efetivada, nem ainda, força de trabalho que excedesse ao requerido pela extração da borracha, que proporcionava ao capital comercial uma rentabilidade extremamente alta.

Por razões semelhantes, não se criam, também, oportunidades de inversão industrial mais expressivas, apesar da existência de mercado, ainda

\footnotetext{
${ }^{7}$ Ver em Santos, História, 1980, pp. 24-27, alguns exemplos da contabilização das contas entre aviadores e produtores, através dos quais se conclui que efetivamente, os fluxos em espécie são predominantes nessas típicas relações.
} 
que de dimensões reduzidas, devido à baixa remuneração dos aviados e à extremamente limitada urbanização. ${ }^{8}$

Com efeito, as características de sua indústria, em 1907 e 1919, refletiam esses negativos aspectos: a indústria da madeira respondia por $25 \%$ da produção industrial da Amazônia; a de bebidas, alimentação e fumo, juntas, representavam outros $25 \%$. A pesquisa de $1907^{9}$ não constatou a existência de indústrias têxteis na região, e, segundo o Censo Industrial de 1919, estas perfaziam apenas 5\% da produção industrial da região.

Vista a estrutura industrial, pela dimensão dos estabelecimentos, os resultados não eram mais promissores: os estabelecimentos maiores concentravam apenas um quarto do capital industrial, tanto quanto a típica estrutura industrial da economia gaúcha, constituída, basicamente, pela pequena e média empresa. A indústria amazônica acompanharia a decadência da economia da borracha: em 1907, a região tinha produção industrial equivalente a 4.3\% do total nacional e, em 1919, já na crise, essa participação era violentamente reduzida para 1.3 por cento.

Por outro lado, dado o elevado número de intermediários em que estava assentada a economia do aviamento, pode-se pensar, ainda, numa relativa atomização do excedente, dificultando, portanto, a transformação do capital comercial em capital produtivo.

Justamente por tudo isto, que exprime a profunda dominação do capital mercantil na economia da borracha, é que boa parte dos lucros se transformou em construções suntuárias, grandes importações de bens de luxo e remessa de rendimento para o exterior, dada a participação do capital estrangeiro no comércio exportador/importador e em vários serviços.

Como essa base produtiva não se diversificou o suficiente para proporcionar a efetiva acumulação de capitais nela gerados, vinda a crise, ao longo da década de 1920, seria quase fatal a sua estagnação e posterior atrofiamento, uma vez que, dadas suas condições naturais, poucas seriam as possibilidades de integração em novas correntes de comércio exterior ou interior. ${ }^{10}$

Com a crise de 1929 e a subseqüente política de defesa da economia, implantada por Vargas, as novas diretrizes econômicas desencadeariam não só a expansão e diversificação industrial do país, mas, principalmente, a formação e integração do mercado nacional. ${ }^{11}$ Este processo, como demonstrei em obra anterior, beneficiou amplamente a economia paulista, mas incorporou a periferia nacional, cujas vendas e compras de São Paulo

${ }^{8}$ Note-se, nesse sentido, que, ainda em 1939 , a população rural perfazia cerca de $75 \%$ da população total da do Norte.

${ }^{9}$ Conforme Centro Industrial do Brasil, 1907, Centro, Brasil, 1908, vol. 2.

${ }^{10}$ A respeito, Furtado, Formação, 1961, cap. 23.

${ }^{11}$ Sobre esses fatos, ibid., caps. 28-32, e Cano, "Furtado", 2006. 
possibilitaram-lhe altas taxas de crescimento econômico e industrial, ao longo das décadas de 1930 à de $1960 .{ }^{12}$

Contudo, a região Norte foi a que menos se beneficiou. Sua primitiva base produtiva e precárias relações sociais de produção não lhes possibilitaram, de imediato, essa integração. Nem mesmo a expansão da indústria nacional de pneumático em meados da década de 1930 faria com que a Amazônia retomasse seus anteriores níveis de produção da borracha. As experiências feitas pelos imigrantes japoneses no cultivo da pimenta do reino, da juta e fibras similares, somente alcançaram plenos resultados após a segunda guerra, o que retardou, em cinqüenta anos, a integração dessa produção com a indústria de sacaria de São Paulo, que floresce desde $1889 .^{13}$

A região Norte apresentaria o pior desempenho agrícola: sua participação nacional cairia de 3.3\% para apenas $1.6 \%$ (e possivelmente sua renda agrícola teria diminuído em 12.3\%) entre 1939 e 1955. A razão fundamental dessa queda poderia em parte ser explicada pelo comportamento depressivo de seus principais produtos de exportação. Entre 1939 e 1955, os preços médios da borracha, ao produtor, cairiam em cerca de 30\% e, ao exportador, em torno de 50\%; as quantidades exportadas para o mercado externo reduziram-se à metade, mas o mercado interno -São Paulo, principalmente- mais que compensou aquela redução, proporcionando um aumento de cerca de $80 \%$ em sua produção física. A castanha do Pará, segundo produto mais importante da Amazônia na época, apresentava crescimento físico nulo na produção e nas exportações e uma redução de $20 \%$ em seus preços ao produtor. Dado que ambos os produtos perfaziam $44 \%$ da produção agrícola da região, não é difícil estimar esse comportamento depressivo, muito embora o cálculo dessa queda de preços resulte da relação entre a evolução nominal desses preços e a do deflator implícito da renda agrícola do Brasil, que usei para deflacionar as rendas agrícolas de cada região, e este deflator é fortemente influenciado pela agricultura do Centro-Sul.

Assim, o mau desempenho da região Norte teve fundamento no comportamento da demanda externa, tanto das quantidades exportadas quanto, principalmente, dos preços. Essa crise só não teve dimensão mais profunda graças ao fato de que desde o início da segunda guerra, a Amazônia começa a integrar-se mais ao mercado nacional, não só em termos de encontrar mercado substituto para a borracha, mas também de abrir novas frentes, como por exemplo, as crescentes exportações de pimenta e fibras

\footnotetext{
${ }^{12}$ Cano, Raízes, 2007.

${ }^{13}$ Sobre o importante papel da imigração japonesa na agricultura amazônica, Homma, Imigração, 2007.
} 
duras (guaxima, malva e juta) para o Centro-Sul do país, onde despontava o mercado paulista, comprador de pelo menos dois terços da produção de borracha e de fibras duras da Amazônia. Com efeito, a integração com o mercado nacional, a partir de meados da década de 1950, alteraria aquele quadro pouco dinâmico, com o crescimento médio anual da agricultura regional superando largamente o nacional.

O período que se estende do imediato pós segunda grande guerra até aproximadamente 1973-1975, trouxe, além do espetacular crescimento econômico, importantes transformações estruturais econômicas (produtivas, do emprego e tecnológicas), políticas (a nova geopolítica com a consolidação da URSS, a descolonização, as democracias formais, etc.) e sociais (as políticas de welfare State, melhorias das condições de trabalho, melhorias da distribuição de renda -estas, em geral apenas para os países desenvueltos), trouxe também maior sensibilização ideológica para com a questão do desenvolvimento. Assim é que entre 1945 e meados da década de 1960, há todo um renascimento da discussão teórica sobre as questões do desenvolvimento econômico -e do subdesenvolvimento-, da questão urbana e da questão regional, temas que passaram, obrigatoriamente, a fazer parte da agenda política dos governos nacionais e dos principais órgãos internacionais.

Os países latinoamericanos também foram tocados por essa forte onda. No plano interno de cada um de nossos países, surgiram também outras pressões sobre aqueles temas, face à urbanização e à industrialização que aqui ocorria fortemente concentradas em pequenas partes do território nacional.

No Brasil, além desses fatos, a magnitude dos investimentos do Plano de Metas se concentrava em São Paulo, sendo que os benefícios (os malefícios viriam mais tarde) da urbanização, igualmente se concentravam em poucas e grandes metrópoles e cidades, notadamente em São Paulo e Rio de Janeiro. Em 1951-1952 se iniciava a publicação das Contas Regionais, possibilitando melhores informações sobre as economias de nossas distintas regiões. Em 1957-1958 as graves secas do Nordeste apareceram "ao vivo" na recém instalada rede de televisão. Tudo isso fez com que a tomada de consciência sobre vários problemas sociais -em particular sobre a questão regional- aumentasse sobremodo.

Daí, a lucidez política de Juscelino Kubitschek levou-o em 1958-1959 a instaurar uma operação Nordeste, que deveria resultar numa política de desenvolvimento regional (primeiro ao Nordeste) cuja elaboração coube a Celso Furtado. Disso surgiram, em 1959-1960, o famoso documento do Grupo de Trabalho para o Desenvolvimento do Nordeste, Uma política de 
desenvolvimento para o Nordeste, ${ }^{14}$ a Superintendência do Desenvolvimento do Nordeste (SUDENE) e seus planos diretores. Outras regiões, notadamente o Norte, também reivindicaram tratamento semelhante, o que faria surgir (além de outras instituições para outras regiões) a Superintendência do Desenvolvimento da Amazônia (SUDAM) em 1966 e a Superintendência da Zona Franca de Manaus (Suframa) em 1967. ${ }^{15}$

A reforma planejada por Furtado não se limitava à industrialização. Dela faziam parte várias políticas de igual magnitude, como as de colonização, reforma agrária e irrigação. Contudo, o golpe de 1964 liquidou com essa proposta ampla, praticamente resumindo as políticas da SUDENE (e mais tarde também as da SUDAM) à de atração de investimentos incentivados na indústria e na agropecuária. A centralização fiscal, política e administrativa imposta pelo regime militar minou a autonomia dessas instituições. A atomização que as mudanças das políticas de incentivos causou, estendendo-os a investimentos que também podiam ser localizados fora dessas regiões -turismo, pesca, reflorestamento, mercado de capitais e Empresa Brasileira de Aeronáutica S. A. (EMBRAER)- acabaram por sucumbir essas instituições regionais, reduzindo suas ações praticamente à política de investimentos privados incentivados, notadamente na indústria. Ainda assim, frutificaram muitos investimentos: indústrias leves, notadamente no Nordeste, agropecuários e de mineração, notadamente no Norte.

Um balanço muito geral do período 1939-1970 mostra, para a região Norte, os seguintes resultados: pequena recuperação em sua participação no produto interno bruto (PIB) nacional em relação aos baixos níveis vigentes entre 1949 e 1960; aumento em sua participação no PIB agrícola nacional graças à sua integração com o mercado nacional; pequena perda de participação no PIB nacional do setor serviços, certamente devida à sua precária urbanização; embora a estrutura produtiva de sua indústria de transformação pouco mudou, sofreu pequena perda de participação no PIB nacional do setor, devido a que entre 1939 e 1949 a região também se beneficiou do efeito da industrialização nacional, tendo sido sua taxa média anual de crescimento do setor de $4 \%$, mas inferior às do Brasil $(7.8 \%)$ e de São Paulo (9.8\%); mas a partir do momento em que sua integração com o mercado nacional cresce, sua taxa se acelera (entre 1949 e 1970) para $8.8 \%$, muito próxima às do Brasil (8.3\%) e de São Paulo (9.2\%), mostrando, no

${ }^{14}$ Furtado, Política, 1967.

${ }^{15}$ Algumas instituições preexistiam: o Banco do Nordeste do Brasil, criado em 1952; a Superintendencia do Plano de Valorizacao Econômica da Amazônia, criada em 1953 à qual sucederia a Sudam, e o Banco da Amazônia S. A., sucessor do Banco de Crédito da Borracha, criado em 1942. A Constituição de 1946 repunha o estabelecido pela de 1934, que concedia 3\% da arrecadação federal pára a região Norte e outro 3\% para o Nordeste. Para mais informações, especialmente sobre o trabalho de Furtado, Cano, Ensaios, 2006. 
fim do período (1967-1970), os primeiros efeitos positivos da Zona Franca de Manaus (ver tabela 2).

As medidas mais importantes - da SudAm e da Suframa- embora criadas antes de 1970, praticamente pouco frutificariam antes dessa data.

\section{A INTEGRAÇÃO ATÍPICA E TRUNCADA ${ }^{16}$}

Esta segunda parte será dividida em períodos específicos: a década de 1970; a "década perdida": 1980-1989; o período 1989-2003: o auge do neoliberalismo, e o período recente: 2003-2010. Com os fatos analisados em cada um dos tópicos tento explicitar a pertinência dessa periodização.

\section{O período 1970-1980}

Este período é caracterizado, em termos da economia nacional, por apresentar elevadas taxas de crescimento e alterações marcantes da estrutura de produção e de emprego, cujos efeitos decorrem das reformas realizadas entre 1964-1965, das diretrizes fixadas pelos Planos Nacionais de Desenvolvimento (PND) I e II, das principais medidas de política econômica, e das circunstancias internacionais que permitiram um enorme endividamento externo para bancar os grandes investimentos públicos e privados, organizados e coordenados por uma forte e autoritária intervenção do Estado.

Sob o ponto de vista regional, ocorre intensa desconcentração produtiva agrícola e industrial, que se deve aos seguintes fatores principais: a) parte das diretrizes da política de desenvolvimento tinham como objetivo expandir e diversificar a produção de insumos básicos, a agroindústria e a infraestrutura -notadamente a hidroelétrica e a construção da rodovia Transamazônica-, segmentos altamente dependentes de recursos naturais, abundantes principalmente nas regiões Norte e Centro-Oeste; $b$ ) decisões macropolíticas do regime militar, em deslocar e desconcentrar do eixo São Paulo-Rio de Janeiro, parte das atividades econômicas ali concentradas, com o que não só tentavam conter o poder político-econômico desta área mas fazer importantes realizações materiais na periferia nacional, para cooptar politicamente suas elites. c) Não se pode ignorar, contudo, que a política de desenvolvimento regional implantada em 1967, a crescente integração do mercado nacional e a urbanização periférica, estimularam também o crescimento agrícola e das indústrias de bens de consumo não durável.

${ }^{16}$ Para o período 1970-2004, Cano, Desconcentração, 2007. 
TABELA 2. PARTICIPAÇÃO (PERCENTAGEM) DA REGIÃO NORTE NO TOTAL DO PIB NACIONAL

\begin{tabular}{lrrrrrr}
\hline & 1939 & 1970 & 1980 & 1989 & $2003^{\mathrm{b}}$ & $2009^{\mathrm{b}}$ \\
& & & & & & \\
PIB total & 2.6 & 2.2 & 3.2 & 4.3 & 4.8 & 5.0 \\
Agricultura & 3.3 & 4.1 & 5.0 & 10.9 & 8.2 & 7.2 \\
Mineração & - & 7.0 & 10.6 & 11.2 & 9.3 & 11.6 \\
Industria transformação & 1.1 & 0.8 & 2.4 & 3.7 & 4.6 & 4.8 \\
Serviços & 2.4 & 2.3 & 2.8 & 3.2 & 4.3 & 4.8 \\
\hline
\end{tabular}

${ }^{a}$ Inclui Tocantins a partir de 1985.

${ }^{\mathrm{b}}$ Nova metodologia das Contas Nacionais e Regionais, a partir de 2002, pelo Instituto Brasileiro de Geografia e Estatística (IBGE).

Fontes: IBGE, Contas Nacionais e Regionais (pós 1969), Censos Agropecuário e Industrial e Pesquisa Industrial Anual (PIA), e Fundação Getúlio Vargas (FGV), para as Contas Nacionais e Regionais entre 1939 e 1969.

Na década, a população urbana cresceu à elevada taxa média anual de 6.7\%, mas a taxa de urbanização ainda seria modesta em 1980 (50\%). Em 1000 habitantes, Belém passava de 633 para 933, e Manaus de 311 para 633. Com a acelerada urbanização, também se desconcentrava parte da produção e emprego em serviços, aumentando a participação nacional do PIB regional do setor, de 2.3 para 2.8 per cento.

Dada a precariedade e não conclusão da Transamazônica, ${ }^{17}$ o projeto de colonização fracassou, embora tenha atraído muitos, em busca do Eldorado da terra. A imigração líquida nacional para a região (para a zona franca de Manaus, e para outras áreas urbanas e rurais), que em 1970 somava cerca de 100000 pessoas, em 1980 atingiria $688000-40 \%$ das quais nordestinas-, e para isso serviram as outras e poucas vias de penetração, notadamente a Rodovia Belém-Brasília.

Com relação à agricultura, foram as culturas tradicionais (arroz, feijão, mandioca e milho, além da pecuária bovina) as que mais cresceram, pouca ou nenhuma presença tendo as culturas modernas de exportação. A despeito disso, a participação da região no PIB agrícola nacional passou de 4.1 para 5\% no período. Nessa expansão, o Pará teve participação um pouco maior do que o Estado do Amazônia.

${ }^{17}$ A Transamazônica cuja construção começa em 1972 a despeito de ter servido de via de penetração e de ter pretendido ser um grande projeto de colonização (as agrovilas), é obra inacabada, em grande parte não pavimentada e sujeita às fortes chuvas da região, o que chega a interromper o tráfego por longos períodos. 
A grande expansão mercantil propiciada pela Zona Franca de Manaus permitiu o amortecimento do desemprego e da subocupação urbanos. Excluída a expansão da agricultura familiar nas grandes inversões no setor rural, preponderou a abertura de fazendas para exploração pecuária que, em vários casos, significou, basicamente, abrir frentes para valorização da terra ao capital especulativo, principalmente o proveniente do pólo $.^{18} \mathrm{Mes}-$ mo assim, não se redimiu a miséria, dados os baixos níveis salariais e a subocupação rural. Por outro lado, a região já demonstrava incapacidade relativa de assimilar as levas migrantes que para lá se dirigiam, principalmente de nordestinos, mormente no setor urbano do Pará. ${ }^{19}$

A extrativa mineral ainda mantinha o manganês como principal produto, e o alumínio e o ferro ainda davam seus primeiros passos na região. Contudo, a participação regional no PIB nacional do setor subiu de 7.6 para 10.6 por cento.

O maior salto se daria na indústria de transformação, não tanto pelos projetos aprovados na órbita da SUDAM, mas, principalmente, pela invenção da Suframa, Zona Franca que, no Brasil, tem a peculiaridade de "exportar para dentro", ou seja, para o mercado nacional, ao contrário das Zonas de Processamento de Exportação. ${ }^{20}$ Graças à magnitude dos incentivos fiscais e financeiros (federais e estaduais), concedidos aos investimentos ali localizados, se transferiram para a Zona Franca de Manaus (ZFM), além de outros segmentos produtivos, parte substancial das indústrias de aparelhos eletrônicos de imagem e de som de São Paulo e Rio de Janeiro.

A participação da região no PIB nacional desse setor subiu de 1.3 para 2.4\%. O estado do Amazônia, graças à ZFM, passa a liderar a indústria regional, detendo $65 \%$ da mesma, saltando sua participação nacional, de 0.3 para $1.5 \%$ enquanto o Pará, que detinha $0.4 \%$ passava-a a $0.7 \%$. Dos sete atuais estados nortistas, além dos dois citados, apenas Rondônia figurava, com apenas 0.1 por cento

Vista essa produção em termos do conceito de uso, seu segmento predominantemente produtor de bens de consumo não durável e o de bens intermediários aumentam suas participações no total nacional, ambos, de $1 \%$ para $1.8 \%$ mas o grande salto foi o do segmento de bens de consumo duráveis e de capital (com produção predominante de aparelhos de som e

${ }^{18}$ Sobre o papel do capital mercantil nas regiões subdesenvolvidas mais atrasadas, Cano, "Reflexões", 2010.

${ }^{19}$ Mahar, Desenvolvimento, 1978, p. 67.

${ }^{20}$ No Mercado Comum do Sul, há outra Zona Franca similar à Zona Franca de Manaus, a Área Aduaneira Especial de Terra do Fogo, na Argentina, conforme Pereira e Romano, Mercosul, 1992. Segundo, Mahar, Desenvolvimento, 1978, pp. 187-188, do total de investimentos industriais realizados na Zona Franca de Manaus até seus dez primeiros anos de existência, 41\%, em média, referiam-se à indústria de têxteis sintéticos e de eletrônica, pouco tendo a ver, com a oferta e demanda da região e sim com o mercado do Centro-Sul. 
imagem, embarcações e veículos duas rodas) que salta de 0.1 para $4.4 \%$. A expansão deste segmento se deu de forma altamente concentrada na Zona Franca de Manaus.

\section{O período 1980-1989}

Chamado de "década perdida", este período se caracteriza por uma depressão em seus três primeiros anos, um crescimento médio anual (19801989) medíocre do PIB (2.2\% para o Brasil e 1.5\% para São Paulo), elevadas taxas de inflação (hiperinflação em 1988-1990), forte queda da taxa de inversão, e uma profunda fragilização fiscal e financeira do setor público, que atingiu as três esferas de governo (federal, estaduais e municipais). Esse debilitamento do Estado fez com que se perdessem os rumos desenvolvimentistas do país, e suas políticas nacional e regional de desenvolvimento. $\mathrm{O}$ corte do gasto público e a queda do investimento privado atingiram negativamente tanto a SUDENE como a SUDAM, que permaneceriam à míngua por longo período.

Os marcos centrais da política macroeconômica eram a difícil luta contra a inflação, o déficit público, os juros, o crédito e o câmbio, numa visão "curtoprazista", que só piorava a situação, engordando as dívidas públicas externa e interna e piorando ainda mais os salários e a distribuição de renda.

Estados e municípios apelariam para a única alternativa que lhes restou: "hipotecar" receitas fiscais presentes e futuras para subsidiar o investimento privado, tentando com isso atraí-lo para seus territórios. Esse fenômeno, chamado de "guerra fiscal", tenderia a se generalizar, a partir da década seguinte, por quase todo o território nacional. Por outro lado, o crescimento da economia só não foi pior -em especial para o Norte e Nordeste, graças a investimentos remanescentes do PND II que ainda seriam conduzidos e (alguns) concluídos até meados da década de 1980.

A região Norte foi a mais beneficiada, com seu PIB crescendo à média anual de aproximadamente $7 \%,{ }^{22}$ graças aos fatos acima e aos seguintes: o de a ZFM ter o mercado nacional cativo para sua produção, fato realçado pelas restrições que sofriam as importações do exterior. Acrescente-se que a inflação, restrições creditícias e cambiais e custos crescentes, e ausência de maiores benesses do Estado para a indústria concentrada no Centro-

${ }^{21}$ Salvo quando se fizer menção diferente, os dados de Tocantins (criado por desmembramento de Goiás e incorporado à região Norte em 1988 pela Constituição Federal), já estão incorporados à região Norte.

${ }^{22}$ Taxa estimada através da variação das participações da região no total nacional, entre 1980 e 1989 . 
Sul -notadamente em São Paulo- estimularam ainda mais a continuidade da transferência da produção de vários segmentos industriais para a Zona Franca de Manaus; e as exportações -notadamente de commodities- passaram a ser fortemente estimuladas, alargando os horizontes da fronteira agromineral da região, mais especificamente da pecuária e da mineração de minerais metálicos.

Vejamos sucintamente os traços mais marcantes do período. A agricultura, mais concentrada no Pará, teve dois principais vetores de crescimento: a pecuária fortemente subsidiada, concentrando ainda mais a propriedade fundiária e a agricultura de tipo familiar, de culturas tradicionais e pequena produção animal. As culturas modernas de exportação dariam seus primeiros passos só no fim do período, pois sua notável expansão se dava no Centro Oeste. Graças a esses três segmentos, o PIB agrícola do Norte aumentou substancialmente sua participação no total nacional, de cinco para 10.9 por cento.

A participação da extrativa mineral passou de 10.6 para $11.2 \%$ do total nacional só não aumentando mais devido à espetacular expansão da atividade petrolífera do Rio de Janeiro na Bacia de Campos. Em 1989, a produção de minerais metálicos passou a representar $27.4 \%$ do total nacional, e as de minerais não metálicos, 17.4\%. As principais atividades da mineração no Norte estavam situadas em sua maior parte no Pará, e eram as de ouro, principalmente o de Serra Pelada -a produção do Norte triplicou no período e atingiu uma participação de 53\% no total nacional-; do ferro, com o início da exploração de Carajás pela Companhia Vale do Rio Doce, atingindo $17 \%$ do total nacional; extração de bauxita, tornando o Pará responsável por 78\% da produção nacional -a produção de alumínio propriamente dito, seria iniciada a partir de 1985, ganhando maior destaque na década posterior-, e cassiterita e manganês seriam os outros dois principais produtos.

Foi medíocre o crescimento da indústria de transformação do Brasil, com a média anual de $0.9 \%$, mas a da região foi de $6.5 \%,{ }^{23}$ daí ter sua participação nacional subido de 2.4 para 3.9\%, concentrando o Amazonas 71\% dessa produção e o Pará 22 por cento.

Dado que o último censo industrial foi o de $1985,{ }^{24}$ só se pode avaliar a mudança estrutural regional entre 1980 e 1985, e ela mostra pequena redução na participação dos bens de consumo não durável e de intermediários, e um aumento mais expressivo (de 45.6 para 51.7\%) de bens de consumo durável e de capital, basicamente presentes na Zona Franca de Manaus. Esta passava a apresentar elevadas participações na produção

\footnotetext{
${ }^{23}$ Ver nota anterior.

${ }^{24}$ Instituto, Censo, 1985.
} 
nacional de madeira e seus artefatos $(12 \%)$, aparelhos receptores de som e imagem (66\%), cronômetros e relógios (78\%) e veículos "duas rodas" e embarcações (36\%). Com exceção de madeiras, esses foram os principais segmentos deslocados da produção paulista, reforçando o processo de desconcentração produtiva espúria. ${ }^{25}$

Se a fronteira agromineral permitiu notável expansão de suas exportações, que passam a perfazer $4.8 \%$ das nacionais, as importações (majoritariamente da Zona Franca de Manaus), passavam a 7.3\%, gerando crescentes déficits comerciais com o exterior. ${ }^{26}$

Entre os censos demográficos de 1980 e de 1991, a taxa média anual de crescimento da população urbana foi de $5.2 \%$-a mais alta taxa regional do país-, e sua taxa de urbanização saltou de 50 para $58 \%$. Do incremento da população total, 73\% se deu no mundo urbano. Belém e Manaus atingiram, respectivamente, 1245 e 1011 milhão de habitantes, situando-se entre as doze maiores cidades do país. A região já contava com oito outras cidades (das quais quatro capitais estaduais) com população entre 116000 e 287000 habitantes.

Assim, essa expansão não se deu apenas nas zonas já urbanizadas, deslocando a urbanização para o interior, notadamente pelas frentes de expansão da fronteira agromineral, que apenas se iniciava nessa década, mas que ganharia maiores resultados nas seguintes. $\mathrm{O}$ fluxo líquido imigratório aumentou, somando, entre aqueles censos, 731000 pessoas (das quais 49\% nordestinas), pouco inferior ao de São Paulo (763 000), mas quase o dobro do que foi para o Centro Oeste (407 000).

A população economicamente ativa (PEA) total aumentou em 1400000 pessoas, com a agricultura absorvendo apenas 285000 , pelas razões acima apontadas. A indústria total absorveu outras 255000 , enquanto a de transformação recebeu o adicional de apenas 102000 pessoas e a extrativa mineral apenas 75000 . O grosso do aumento da ocupação (928 000) se deu no setor serviços. Este último cujo PIB se estima que tenha aumentado em $52 \%{ }^{27}$ entre 1980 e 1991, mostrou, entretanto, aumento do emprego de $122 \%$, ocultando assim o elevado número de ocupações de baixa produtividade (subemprego) e de baixos salários, e revelando o aumento potencial do desemprego aberto. Dado seu crescimento mais modesto (pela ótica da renda), a participação regional no PIB terciário nacional subiu de 2.8

${ }^{25}$ Em Cano, Desconcentração, 2007, explico a diferença entre a desconcentração virtuosa da década de 1970 que é aquela que ocorre mesmo com forte crescimento de São Paulo. Ao contrário, a espúria decorre tanto de efeitos causados pela guerra fiscal quanto os resultantes de meros efeitos estatísticos decorrentes da relação entre as baixas taxas de crescimento (positivos ou negativos de São Paulo vis-à-vis as de outras regiões do pais, igualmente baixas.

${ }^{26}$ Mota, "Inserção", 2010, cap. 3.

27 Ver nota 21. 
para 3.8\%, e os segmentos que mais cresceram foram os mais tradicionais, como o comércio e atividades de alojamento e alimentação, revelando o caráter mais pobre e subdesenvolvido dessa urbanização.

\section{O período 1989-2003: o auge do neoliberalismo}

O período se caracteriza pela implantação das reformas neoliberais do Consenso de Washington: a desregulamentação do sistema financeiro nacional e dos fluxos internacionais de capital, abertura comercial, flexibilização das relações capital-trabalho, previdência social, privatização, forte diminuição do papel do Estado e "reforma administrativa" do setor público. Para atingir os objetivos do capital internacional -a globalização comercial e financeira e a abertura dos mercados internacionais-, houve radical mudança na política de estabilização, ${ }^{28} \mathrm{com}$ acentuada valorização cambial, desmedida elevação da taxa de juros, corte do crédito e severo controle do gasto público.

Os resultados não demoraram, a partir de julho de 1994, quando se institui o Plano Real de estabilização e se implantam de forma mais intensa reformas ainda mais liberalizantes. A despeito da redemocratização e da Constituição Federal de 1988, o governo federal conseguiu recentralizar parte importante da receita fiscal total, insuficiente, contudo, para pagar os próprios juros sobre a dívida pública.

Com isso, o debilitamento fiscal e financeiro do Estado federal aumentou, reestruturando-se via drástico corte de gastos e investimentos públicos. Os governos estaduais e municipais foram, na prática, obrigados a negociar com o governo central suas dívidas, que lhes impôs duras regras financeiras, imobilizando também seus investimentos, e recentralizando ainda mais as finanças na órbita federal. A abertura comercial e a forte valorização do câmbio prejudicou ainda, pesadamente, a produção nacional (notadamente a industrial). ${ }^{29}$ Os juros elevados, o baixo crédito, a concorrência externa e a contenção do gasto público, inibiram fortemente o investimento privado. Dessa forma, o crescimento foi estimulado pelo (modesto) aumento das exportações (principalmente de commodities, cujos preços externos caem no período), forte expansão do comércio (importador e geral) e pelo consumo familiar, que cresce induzido pela melho-

\footnotetext{
${ }^{28}$ Lembremos que predominou, entre 1988 e julho de 1994, um regime altamente inflacionário, que em alguns momentos revelou-se como de hiperinflação.

${ }_{29}$ O livro de Carvalho, Globalização, 2006, contém alguns ensaios sobre essas circunstâncias e seus efeitos sobre a economia Amazônica, em especial, do Fundo de Financiamento Constitucional para o Norte.
} 
ria da distribuição de renda causada pela estabilização e pela valorização cambial.

Em todo esse período, a estabilização primou sobre o desenvolvimento. Os principais órgãos federais de planejamento econômico, já debilitados no período anterior, foram desmantelados. Idêntico fenômeno ocorreu com a SUDENE e SUDAM, que chegam a ser extintas em 2001 e recriadas em 2007. ${ }^{30}$ Atitudes de planejamento e desenvolvimento na órbita regional tiveram igual destino. Daí que restaria às unidades federadas e a vários municípios o uso indiscriminado da guerra fiscal.

Em termos de crescimento econômico nacional, o período foi tão ruim como o anterior: o PIB cresceu à taxa média anual de $2.2 \%$ e a indústria de transformação foi o setor que menos cresceu $(0.6 \%)$, despencando sua participação no PIB total, de 31\% em 1989 para 19\% em 2004, revelando uma precoce desindustrialização. ${ }^{31}$ Para a região, contudo, o PIB cresceu a $4.9 \%$. As exportações da região cresceram à média anual de 7.2\% (em dólares correntes), e passaram de 4.6 para $5.7 \%$ do total nacional. A proporção de manufaturados na pauta subiu, de pouco menos de $20 \%$ para pouco mais de 35\%. Ainda assim, acumulou déficits importantes entre 1994 e 2002, anos "de ouro" da enxurrada de importações. ${ }^{32}$

Para o conjunto do Brasil, o setor agrícola foi o que mais cresceu (taxa média anual de 4.1\%) mas na região Norte seu crescimento (2\%) foi modesto, ainda menor do que o de sua área colhida (2.7\%). Conviveu isto sim, com a expansão predominante das culturas simples (mandioca, arroz, feijão, milho e outros), culturas típicas da agricultura familiar. A pecuária bovina apresentou enorme expansão, cujo rebanho aumentou $158 \%$; soja e sorgo davam seus primeiros passos na Amazônia, principalmente em Tocantins, Rondônia e Pará, apresentando taxas elevadíssimas de expansão, mas ainda obtendo pequenos volumes absolutos de produção. Lembremos que no início e meados desse período estavam baixos os preços internacionais das commodities agrícolas.

Os dados oficiais mostram que a participação da região no PIB nacional da indústria extrativa mineral, cai de 11.2 para $9.3 \%$, em que pese o extraordinário aumento da produção e exportação de vários minerais da região, notadamente do ferro e alumínio. São duas as razões para isso: a forte queda dos preços internacionais no período e a grande elevação da extração petroleira no Rio de Janeiro, fazendo com que a participação desse estado aumentasse de 4\% em 1980 para 78\% do PIB setorial em 2004.

\footnotetext{
${ }^{30}$ Em 2001 foram substituídas por duas Agências Reguladoras (Agência de Desenvolvimento dão Nordeste e Agência de Desenvolvimento da Amazônia) e estas extintas em 2007.

${ }^{31}$ Sobre o fenômeno, Cano, Desindustrialização, 2012.

${ }^{32}$ Sobre evolução e impactos do comércio externo nas estruturas regionais brasileiras, Mota, "Inserção", 2010, cap. 3.
} 
Na região, o setor já representava $25 \%$ da produção nacional de minerais metálicos e seu setor como um todo, cresceu à média anual de 3.7\% enquanto a nacional foi de 5.5\%. O ferro continuou a liderar o setor na região, seguido pelo ouro, bauxita, manganês e níquel.

No que se refere à indústria de transformação, se passa fenômeno distinto: a taxa média anual do Brasil foi de apenas $0.6 \%$ mas a da região foi de 9.4\%, fortemente influenciada pela do Amazonas (12.0\%) e concentrada na Zona Franca de Manaus, enquanto o Pará obtinha apenas 2.1\%. Em 2003, a região concentrava $4.6 \%$ da produção nacional, $72 \%$ da qual estava no Amazônia e 22\% no Pará.

Essa indústria cresceu e se diversificou, mas predominantemente em bens de consumo durável. A participação nacional do Norte (notadamente a Zona Franca de Manaus, salvo em madeiras e metalurgia não ferrosa) em termos de seus principais segmentos produtivos passou a ser a seguinte, entre 1985 e 2003: madeira serrada de 12 para 14\%; celulose de 3 para $6 \%$; metalurgia não ferrosa de 1 para $17 \%$; equipamentos eletrônicos para informática de 2 para $8 \%$; material eletrônico básico de 8 para $28 \%$; aparelhos eletrônicos transmissores (principalmente celulares) de 5 para $45 \%$; receptores de som e imagem de 66 para 77\%; aparelhos óticos, fotográficos e cinematográficos de 8 para $23 \%$; cronômetros e relógios de 78 para $86 \%$, e embarcações e veículos "duas rodas" de 36 para $76 \%$.

O avanço da urbanização e da indústria fez com que o PIB terciário aumentasse à taxa média anual de $3.9 \%,{ }^{33}$ com o que a participação da região nesse PIB nacional sobe de $3.2 \%$ para $4.3 \%$ nesse período.

Embora entre os censos demográficos de 1991 e 2000 a taxa de crescimento da população urbana caísse para $4.7 \%$ anuais, ela foi a mais alta entre as regiões do país, assim como a da população total (2.9\%), e a taxa de urbanização elevou-se a cerca de 70\%. Enquanto a população total aumentou em 2600000 pessoas, a PEA ocupada cresceu em apenas 750000 , sendo que a rural diminuiu (-144000), a despeito da expansão agrícola. A ocupação industrial aumentou em apenas 70 000, devido à desocupação de 82000 na extrativa mineral e aos aumentos de 75000 na construção civil e 77000 na indústria de transformação, apesar do extraordinário crescimento da produção deste setor. Dessa forma, foram os serviços o setor que mais empregou (824 000), entre os quais o serviço doméstico adicionou 144000 e o da categoria "ocupados sem remuneração nos demais setores urbanos" outros 61000 .

As médias anuais dos fluxos imigratórios ${ }^{34}$ do período 1991-2000 foram três vezes menores do que as do período anterior, enquanto os fluxos

${ }^{33}$ Obtida por estimativa usando as proporções regionais e o crescimento nacional.
${ }^{34} 78 \%$ constituídos por nordestinos. 
de saída quase dobraram. Assim, o total de entradas líquidas no período foi de cerca de apenas 133000 pessoas, parecendo indicar um possível "fechamento" daquele Eldorado, o qual, esperamos, tenha sido apenas transitório.

\section{O periodo recente: $2003-2010$}

Este período, que compreende sete dos oito anos dos mandatos do presidente Lula, trouxe importantes mudanças. No plano externo, uma elevada fase de crescimento da economia e do comércio internacional, especialmente da China e de vários países asiáticos, com forte alta da demanda e dos preços das commodities, e forte expansão dos fluxos de capitais forâneos -em parte produtivos, mas em parte fortemente especulativos- em direção aos países subdesenvolvidos, compensando nossos crescentes déficits externos e ainda gerando um grande excedente que valorizou fortemente a taxa de câmbio durante todo o período.

No plano interno, as principais mudanças da política econômica foram a expansão do crédito ao setor privado, notadamente o pessoal, via decisiva atitude do Estado e dos bancos públicos, o que realimentaria o consumo familiar; uma pequena redução da (elevada) taxa de juros, somente a partir de outubro de 2006, mantendo-a entretanto em cerca de $9 \%$ anuais até fins de 2009, mas ela subiria de novo, atingindo $10.5 \%$ em julho de 2010, 12.4\% em agosto de 2011 e começaria a cair em abril de 2012 com 9.5\%; ativação de políticas sociais -notadamente o Bolsa Família e a elevação real do salário mínimo- que deram uma certa melhoria na distribuição de renda e um novo alento ao mercado de bens de consumo, e com maior expressão a partir de 2006, uma modesta elevação do investimento público federal.

A reativação do consumo familiar e a expansão das exportações estimularam o investimento e a economia passou a ter taxas mais altas de crescimento da renda e do emprego. Com efeito, a substancial elevação dos preços externos e o aumento da demanda asiática fizeram com que as exportações da região crescessem à média anual de 15.7\%, com saldos superavitários em todos os anos, e com os manufaturados perfazendo cerca de 30\% da pauta exportadora. Contudo, essa rota de crescimento calcado nas exportações de commodities e no consumo familiar -a despeito da expansão do investimento-, é mais suscetível do que outras para alterar a trajetória da economia. Com efeito, vinda a crise internacional de 2008, a economia nacional foi atingida em cheio. As políticas anticíclicas do Estado permitiram rápida recuperação em fins de 2009 (não para a taxa 
de investimento), mas a crise europeia em 2011 novamente deprimiria a economia nacional.

Dessa forma, e em que pese as elevadas taxas de crescimento em 2004 e 2006-2008, a média para o período 2003-2010 foi de apenas 3.9\%, pouco acima do período precedente. Para dificultar ainda mais esse quadro, a elevada valorização do câmbio ampliou desmedidamente as importações e deprimiu as exportações de produtos manufaturados, ${ }^{35}$ os quais, que chegaram a representar pouco mais de $60 \%$ do total das exportações nacionais, caíram a 37\% em 2012. Este fato tornaria ainda mais problemática a trajetória da economia.

Sob o ponto de vista da economia regional, a ausência de uma política de desenvolvimento regional continuou, assim como os recursos financeiros para isso também minguaram. $\mathrm{O}$ que prevaleceu no período foram, além da guerra fiscal, alguns investimentos fortemente apoiados pelo Estado (governo e estatais) e subsidiariamente assumidos pelo setor privado, basicamente em energia e transportes, em grande parte localizados no Norte e Nordeste do país. Além disso, o grosso do investimento privado dirigiu-se aos setores agroexportador, de mineração e de serviços (notadamente os financeiros).

Guerra fiscal e valorização cambial seriam os piores inimigos da indústria - principalmente da sediada em São Paulo-, causando-lhe desestruturação de várias cadeias produtivas. Mas essa desconcentração espúria não afetou apenas os estados mais industrializados, pois aqueles que mais se beneficiaram com esses investimentos subsidiados também sofreram percalços com a enxurrada de importações que se manifesta durante todo este período. Vejamos sucintamente o movimento da economia da região Norte no período (ver tabela 3).

A Agricultura teve um comportamento modesto, com o PIB nacional crescendo à taxa média anual $2.5 \%$ e o do Norte à de apenas $1.1 \%$. A área colhida aumentou apenas 190000 hectares, com as principais culturas tradicionais de pequena e média produção diminuindo-a em 150 000, o que se traduziu também em quedas de produção em torno de 15\%. A área com soja cresceu 280 000, além do aumento das áreas de cana e sorgo. Em que pese sua expressiva expansão, a soja representa apenas $2.5 \%$ da produção nacional. No que se refere à madeira, os dados da produção mostram drástica redução da produção de carvão vegetal, um estancamento na de lenha e considerável redução na de madeira em toras. Contudo, o desmatamento continuou, dado que o rebanho bovino atingiu a elevada cifra de 40400000 cabeças, ou 20\% do rebanho nacional.

${ }^{35}$ Sobre a desindustrialização, que se agrava no período, ver Cano, Desindustrialização, 2012. 


\section{TABELA 3. ESTRUTURA PRODUTIVA DA REGIÃO NORTE $(\text { EM PORCENTAGE) })^{\mathrm{a}}$}

\begin{tabular}{|c|c|c|c|c|c|c|}
\hline & 1939 & 1970 & 1980 & 1989 & $2003^{\mathrm{b}}$ & $2009^{b}$ \\
\hline PIB total & 100 & 100 & 100 & 100 & 100 & 100 \\
\hline Agricultura & 35.5 & 23.6 & 16.1 & 20.0 & 12.9 & 7.8 \\
\hline Ind. total & 16.6 & 15.1 & 37.2 & 35.0 & 29.6 & 28.1 \\
\hline Mineração & - & - & - & 2.2 & 3.2 & 4.0 \\
\hline Transformação & - & - & - & 24.7 & 17.0 & 13.5 \\
\hline Construção & - & - & - & 6.5 & 6.5 & 7.7 \\
\hline Serviços & 47.9 & 61.3 & 46.7 & 45.0 & 57.2 & 61.8 \\
\hline
\end{tabular}

${ }^{\text {a }}$ Inclui Tocantins a partir de 1985.

${ }^{\mathrm{b}}$ Nova metodologia das Contas Nacionais e Regionais, a partir de 2002.

Fontes: IBGE, Contas Nacionais e Regionais, Censos Agropecuário e Industrial e Pesquisa Industrial Anual; e Fundação Getúlio Vargas (FGV), para as Contas Nacionais e Regionais entre 1939 e 1969.

Reproduz-se na Amazônia o que Furtado denominou de agricultura itinerante, processo em que a agricultura de exportação e o latifúndio pecuarista deslocam espacialmente a agricultura familiar, destruindo-a e recriando-a. Ainda assim, a ocupação do setor cresceu 24.7\% (mais 285000 pessoas) entre 2000 e 2010, mas a estimativa que faço para os ocupados em auto-consumo no próprio setor teria mais que duplicado seu número no mesmo período, pois teriam passado de 207000 para 440 000, e seu aumento, de 233000 pessoas, equivaleria a 82\% do aumento total da PEA agrícola. ${ }^{36}$

Embora essa ocupação tenha crescido em todos os estados da região, o Pará concentra 47\% dela. Dado positivo é que os ocupados sem remuneração diminuíram fortemente, não só pela mudança estrutural, pela reforma agrária do período mas também pela maior fiscalização do Ministério do Trabalho.

O PIB da indústria extrativa mineral cresceu à média anual de 5\%, bem acima da média do Brasil (3.7\%), com o que sua participação nacional elevou-se, de 9.3 para $11.6 \%$, e seu peso na estrutura produtiva regional subiu de 3.2 para $4 \%$. A região Norte passou a representar $26 \%$ do valor

${ }^{36}$ A hipótese está calcada na admissão de que os dados divulgados do censo de 2010 estão corretos. A estimativa foi feita multiplicando-se a relação autoconsumo na agricultura/autoconsumo total verificada no censo de 2000 , que era de 0.8873 pela autoconsumo total do censo demográfico de 2010 que foi de 496000 pessoas. 
da produção mineral (exclusive petróleo e gás), com o Pará concentrando cerca de $90 \%$ dela.

Em minerais metálicos (quase 70\% do valor da produção mineral da região), só foram fracos os desempenhos da cassiterita e do manganês, a primeira tendo queda de produção de $25 \%$ e o segundo tendo crescimento quase nulo. $\mathrm{Na}$ dos outros quatro principais minerais (representando, juntos, $90 \%$ do valor da produção de minerais metálicos) houve grandes saltos na produção física do período: a mínima de $19 \%$ no ferro, $28 \%$ na do níquel, $47 \%$ da do ouro, e a do cobre crescendo sete vezes.

Parte importante desse crescimento se deu via preços internacionais, que praticamente dobram no período. Contudo, cabe criticar que na estrutura nacional das exportações minerais em 2003, os manufaturados, que compreendiam 31\%, caem, atingindo somente 19\% em 2009. E essa participação desses manufaturados, na pauta regional, certamente foi ainda mais nociva. Lembremos que a relação entre os preços das matérias primas (minério apenas beneficiado) e as manufaturas estão na proporção de 1:4 no caso do cobre, 1:16 no do ferro, e 1:40 no alumínio, o que mostra a precariedade de atitudes mais responsáveis do Estado a respeito dos interesses nacionais nesse setor. Recentemente, por exemplo, o Estado permitiu que a Companhia Vale do Rio Doce alienasse suas jazidas e plantas de alumínio para um dos maiores trustes internacionais desse setor. ${ }^{37}$

A indústria de transformação foi o setor que mais se debilitou no período, pelas razões macroeconômicas acima apontadas, e principalmente pela valorização cambial, que exacerbou o crescimento das importações de insumos e produtos industriais finais de toda ordem. Não fosse a implantação de políticas anticíclicas em 2009, os resultados seriam ainda piores. Com isso, seu PIB cresceu à taxa média anual de apenas $2.2 \%$ no Brasil e de $3.2 \%$ na região, praticamente mantendo a participação nacional da região no período. ${ }^{38}$ Dado esse crescimento inferior e diferenciado em relação aos outros setores do PIB, bem como à mudança metodológica feita nas Contas Nacionais e Regionais a partir de 2002, a participação do setor no PIB total caiu também na região, passando dos $24.7 \%$ em 1989,

${ }^{37}$ Fato ocorrido em 2010, quando vendeu o controle de suas minas e plantas (91\% da Alunorte, $81 \%$ da Companhia Alumina do Pará e 51\% da Albrás), do segmento de alumínio para a norueguesa Norsky Hydro negócio que atingiu a soma de 4.9 bilhões do dólar, conforme "Matéria sobre investimentos estrangeiros", O Estado de São Paulo, 3 de maio de 2010, p. B12.

${ }^{38}$ Há problemas metodológicos complexos entre as Contas Regionais que utilizo nos dados acima e os dados obtidos por outras pesquisas oficiais (como a Pesquisa industrial anual, por exemplo), provavelmente devido a diferenças de composição no valor de transformação industrial e no valor agregado bruto dessas variáveis. No caso acima, dado que a taxa de crescimento do Norte foi ligeiramente superior à do Brasil, sua participação nacional deveria ter aumentado ligeiramente (conforme está na tabela 2), e não caído, como se concluiria pela série de valor agregado bruto, das Contas Regionais. 
para 17\% em 2003 e somente 13.5\% em 2009, mostrando claramente a desindustrialização que também atinge as indústrias regionais, a despeito da guerra fiscal.

Para este período, não conto com as tabulações especiais do Instituto Brasileiro de Geografia e Estatística que pude usar para os anteriores. Assim, só estão disponíveis os dados a dois dígitos publicados pelas PIAS e os da Zona Franca de Manaus. Comparadas as PIAS de 2003 e 2009, se constata que a participação da região nos ramos em que já apresentava uma expressiva concentração nacional, aumentou: é o caso de impressão e reprodução de gravações, equipamentos e materiais eletrônicos e de informática (no qual se destacam: celulares, som e imagem e informática), e outros equipamentos de transporte (destaque para o segmento de motocicletas). Os dados de faturamento e produção física da ZFM confirmam esse movimento.

O PIB do setor serviços foi o que mais cresceu, com média anual de $5.5 \%$, acima da do Brasil (4.3\%), ampliando a participação da região no total nacional, para $4.8 \%$. A população urbana cresceu à taxa média anual de $2.6 \%$ atingindo 11600000 pessoas, fazendo com que a taxa de urbanização subisse para 73.5\%. Com isso, aumentou o número de cidades com mais de 100000 habitantes, de catorze para 21 (entre as quais as sete capitais), com várias delas inseridas em pontos focais da expansão da fronteira agrícola e da mineral, esta, especialmente no Sudeste Paraense. ${ }^{39}$

Como fato inusitado, no período 2000-2010, a PEA total cresceu 51\%, bem acima do aumento da população rural $(8 \%)$ e da urbana (34\%). No da PEA não-agrícola, que cresceu $61 \%$, destaque-se o forte aumento da indústria de construção civil (87.7\%), e da de transformação somente $23.5 \%$, gerando apenas 85000 novos empregos. No setor serviços, que aumentou $64.6 \%$, e respondeu por $71 \%$ do aumento total do emprego, os dados divulgados em 2010 dificultam a comparação entre seus principais segmentos, com os dados de 2000. O emprego doméstico, embora tenha crescido bem menos (31\%), respondeu por 95000 novas ocupações, em que pese as dificuldades de comparação, os dados da PEA revelam uma estrutura ocupacional urbana compatível com a precária urbanização da região e com as ambiguiidades da estrutura produtiva, onde sobressaem como setores mais dinâmicos, exatamente os menos empregadores.

\footnotetext{
${ }^{39}$ Monteiro, "Economia”, 2011, faz importante análise sobre essa região, destacando os efeitos econômicos e urbanos dessa expansão.
} 


\section{CONCLUSÕES}

A recuperação e expansão da Amazônia ao longo do período pós crise de 1929, também se faz presente nos dados demográficos: de 3.9\% da população total nacional em 1939, passou a 8.3\% em 2010, e, quanto à urbana, as cifras respectivas são 3.2 e $7.2 \%$, sendo a região de maior crescimento, se excluirmos do Centro Oeste, o Distrito Federal.

Contudo sua população, em que pese o progresso material ocorrido nesse longo transcurso, padece de sérios problemas, sendo a segunda pior região do país em analfabetismo, escolaridade, mortalidade infantil, atendimento de serviço de água, de luz elétrica e de coleta de lixo, e a pior em esgoto sanitário. Daí ter alguns dos piores indicadores regionais em saúde, com forte incidência em várias doenças graves, como tuberculose, hanseníase, Chagas, leishmaniose visceral, dengue e malária.

Mas sua urbanização é tão problemática quanto a do resto do país, padecendo das mesmas mazelas urbanas, como favelização, periferização, transporte, habitação e segurança, bem como das deficiências no atendimento ao controle e planejamento urbanos e na especulação imobiliária.

Há cerca de 40 anos, a Amazônia passou a participar ativamente da agenda de governo, de políticos e de cientistas sociais, com temas sobre seu futuro, isto é, sobre o que e como deveria ser feito com a economia da região e com sua exuberante base de recursos naturais. Dessa agenda também fizeram (e fazem) parte pessoas e instituições internacionais, mormente aquelas voltadas para a defesa do meio ambiente. Mas também fizeram e fazem parte instituições internacionais financiadas por governos e empresas estrangeiras, muitas vezes suspeitas de defenderem -já de longa data-, e de várias formas, uma suposta internacionalização da região. Entre as mais esdrúxulas, lembro do absurdo projeto apresentado em 1969 por Herman Kahn -do Hudson Institute e da Rand Corporation- para alagar uma imensa área da Amazônia, sob o pretexto de "facilitar a circulação de pessoas e dar maior acesso aos recursos naturais".

Foram muitas as propostas, inclusive a de dar vazão ao excedente demográfico nordestino -e, com isso, evitar uma reforma agrária nacional-, praticando uma colonização -com as então chamadas "agrovilas"- ao longo da rodovia Transamazônica. Discutia-se também a impossibilidade de uma ocupação territorial humana, dadas as condições e a imensidão do território. Talvez com gado bovino, o que efetivamente se fez, não ocupando plenamente o território, mas aumentando o desmatamento. Vários 
cientistas sociais da região externaram suas sinceras preocupações com os supostos destinos. ${ }^{40}$

Passados todos esses anos um balanço que se pode fazer da região terá que, necessariamente, apontar criticamente os principais efeitos positivos e negativos desse processo.

A ocupação acabou tendo um sentido maior de exploração de recursos naturais: a terra apropriada, entre 1970 e 2006 passou (em milhões de hectares) de 23 a 55, dos quais a pecuária passou de 4.4 para 26.5, as lavouras, de 0.5 para 4.2 e as matas de 13.8 para 22.3; a despeito da realização de muitos assentamentos familiares, a concentração latifundiária e a especulação com a terra cresceu expressivamente, e o número de conflitos fundiários se multiplicou; essa expansão causou, ainda, um maior desmatamento, cuja taxa média anual calculada pelo Instituto Nacional de Pesquisas Espaciais ${ }^{41}$ acusa cifras (em $1000 \mathrm{k}^{2}$ ) de 25 para os anos 2003-2004, 16.5 para 2005-2006, doze para 2007-2008 e de sete para 2009-2011; em 2009, a extração de minério de ferro atingia cerca de 92 e a de bauxita 26 , ambas em milhões de toneladas, e a exploração de recursos hídricos permitiu grande expansão na geração de energia elétrica, com a região participando com $12.4 \%$ do total, embora seu consumo perfaça 6.4 por cento. ${ }^{42}$

A região foi beneficiada por uma dotação especial de infra-estrutura, além de grandes projetos hidroelétricos federais -constituída de meios de transporte e de comunicações, indispensável para dar vazão ao exterior de parte preponderante de seus novos segmentos produtivos como madeira, celulose, minérios e agricultura de exportação. É óbvio que essa infraestrutura está, teoricamente, também disponível para outros segmentos produtivos.

Como se viu ao longo do texto, a produção de todos os macro setores (agricultura, extrativismo, mineração, indústria e serviços) cresceu acima da média nacional, nela aumentando sua participação. Contudo é sob o ponto de vista do emprego, que as contradições desse processo mais se agudizam: a despeito da elevada expansão da área rural apropriada, e de sua modernização, o setor segue com uma estrutura ocupacional muito precária. Por outro lado, no que se refere ao emprego urbano e industrial, há que ter presente o fato de que o setor mais dinâmico é o da extrativa

${ }^{40}$ Cabe lembrar entre eles, Mendes, Anúncio, 1979, que criticava a falta de clareza dos objetivos dos projetos governamentais para a região e perguntava: "desenvolvimento de quem?"; "para quê; “...que desenvolvimento?”; e o de Monteiro, Amazônia, 1979, que imaginava a possibilidade de um desenvolvimento baseado na pequena e média empresa, não predatório de recursos e em um sentido maior de justiça social. Fez-se, infelizmente, muito daquilo que esses críticos temiam. Venceu a selvageria do capitalismo brasileiro.

${ }^{41}$ Ver programa de monitoramento do Instituto Nacional de Pesquisas Espaciais, 2012, em Instituto, "Monitoramento", 2012.

${ }^{42}$ Ver Balanço, 2011, e Empresa, Resenha, 2012. 
mineral, escassamente empregador, dificultando assim uma expansão produtiva e ocupacional urbana mais moderna e eficiente.

Após 44 anos da instalação da Zona Franca de Manaus, sua indústria de transformação continua problemática como antes. Vejamos alguns indicadores e relações, como percentagem (aproximada) sobre o faturamento total da ZFM, comparados nos períodos 1988-1989 e os anos mais recentes: $:^{43} a$ ) insumos importados, de 9 passou a $40 ; b$ ) insumos regionais, caiu de 18 para $14 ; c$ ) insumos nacionais de outras regiões, caiu de 21 para 12 , atingindo especialmente a indústria paulista; $d$ ) exportações para o exterior (para o mercado nacional), de 1 para 3.5 (de 99 para 96.5); e) importações do exterior (do mercado nacional), 10 para 27 (42 para 23).

Temos notícias de que em alguns dos setores produtivos da ZFM houve aumento de interdependência técnica e produtiva, alargando um pouco suas cadeias produtivas. Contudo, o que os dados acima mostram é que, em média, se progresso houve nestes 40 anos, ele foi mínimo, inclusive com aumento da desnacionalização de várias empresas. Também entendemos, como muitos economistas, que o problema de nossa desindustrialização nacional não se restringe à valorização cambial. Há outros fatores impeditivos de maior competitividade externa que, aparentemente, não estão sendo investigados e tratados com a necessária objetividade empresarial e responsabilidade do Estado.

Mais três importantes pontos negativos devem ser lembrados. O primeiro é o crescente rombo de divisas (em bilhões do dólar) que a Zona Franca de Manaus tem causado: relativamente modesto nos cinco primeiros anos da série (1988-1992) quando soma 2.9 (média anual de 0.6) e elevado, entre 1993 e 2010, quando soma 60.6 (média anual de 3.4). Outro ponto se refere à renúncia fiscal (federal e estadual) na ZFM, para o que não tenho dados recentes, mas somente para o período 1988-1992 quando teria totalizado o equivalente a $21 \%$ do faturamento, cifra muito alta. ${ }^{44} \mathrm{Um}$ terceiro é a questão dos salários pagos na ZFM: em 1988-1992, na estrutura salarial os trabalhadores que recebiam até dois salários mínimos perfaziam $23 \%$ e, nos anos mais recentes, essa cifra subiu para 34\%. No mesmo período, os que recebiam mais de dez salários mínimos passaram de 9.2 para 4.3 por cento.

Devo confessar ser muito difícil se fazer um prognóstico geral sobre o futuro imediato da região, pois são maiores as incertezas e questionamentos do que as evidências positivas. Existem vários grandes projetos em execução, notadamente hidroelétricos, e outros comentados pela imprensa e

\footnotetext{
${ }^{43}$ Além de outras fontes já citadas, os dados coligidos sobre a Zona Franca de Manaus estão em Superintendência, Indicadores, 2012.

${ }^{44}$ Ver Lyra, "Incentivos", 1995.
} 
por grupos empresariais, principalmente de mineração, mas que, a meu juízo, não mudam substancialmente o quadro qualitativo atual; primeiro, porque a região acelerou seu crescimento no último decênio graças ao extraordinário boom do comercio internacional de produtos primários. Contudo, essa onda ao que tudo indica, pelo menos já desacelerou. Por outro lado, a China, o grande comprador mundial, tem nos anos recentes, aberto frentes de exploração em vários países subdesenvolvidos para a extração ou produção de produtos primários similares aos que lhe exportamos; outro ponto, ainda mais relevante, é que o divórcio do Estado brasileiro para com as políticas verdadeiramente desenvolvimentistas, atingiu em cheio a questão regional, truncando o processo virtuoso de integração que tivemos entre 1930 e 1980, desarticulando parte das relações econômicas interregionais e permitindo esse ato antinacional e anti-social que é a guerra fiscal, que só pode promover uma desconcentração espúria e atípica, e não uma virtuosa, como tivemos em nosso passado recente.

Finalizando, esclareço melhor o título do texto: integração atípica e truncada. Atípica, porque, após a instituição da SuFrama os determinantes do processo de integração, que obedeciam basicamente à dinâmica nacional e em especial à paulista, passam a depender mais da política cambial e do conjunto de incentivos (federais e os estaduais, da guerra fiscal). Ao invés de continuar, como parte do território do restante da periferia, transformando suas estruturas produtivas e ampliando sua complementaridade com a economia paulista e com a nacional, apenas serve-se do mercado desta, sem contudo desenvolver uma estrutura industrial de caráter nacional, ou seja que se transforma e integra ao longo do período de sua implantação, incorporando e gerando crescentes economias externas e de escala.

Truncada, porque a política industrial que instituiu a SUFRAMA, de fato se restringiu a uma implantação industrial que pouco difere das maquiladoras mexicanas em termos de estrutura produtiva, mas difere radicalmente delas em termos de mercado exterior e interior. Por outro lado, a partir da abertura neoliberal e, em especial a partir do boom internacional de commodities, as determinações maiores sobre a dinâmica regional passam a ser aquelas emanadas das condições do mercado externo e não do investimento nacional, por sinal fortemente rebaixado pelas políticas macroeconômicas de corte neoliberal, até hoje em grande parte vigentes. ${ }^{45}$

\footnotetext{
${ }^{45}$ Há que se fazer justiça às ações do atual governo -Dilma Roussef-, no sentido de rebaixar a elevada taxa de juros do país, e às medidas anticíclicas tomadas em 2009 e recentemente. Contudo, isso tudo é muito pouco para uma mudança estrutural e uma retomada efetiva do desenvolvimento.
} 


\section{Fuentes CONSULTADAS}

\section{Hemerografia}

O Estado de São Paulo, São Paulo, Brasil.

\section{Bibliografia}

Anuário Estatístico do Brasil, Rio de Janeiro, Instituto Brasileiro de Geografia e Estatística, 1939-1940.

Balanço energético, Brasília, Ministério de Minas e Energia, 2011.

Camargo, José Francisco De, "Crescimento da população no estado de São Paulo e seus aspectos econômicos”, Boletim da Faculdade de Filosofia, Ciências e Letras, Universidade de São Paulo, núm. 153, 1953, São Paulo.

CANO, Wilson, "Crise de 1929: soberania na política econômica e industrialização" em Wilson CANO, Ensaios sobre a formação econômica regional do Brasil, Campinas, Universidade Estadual de Campinas, 2006.

Ensaios sobre a formação econômica regional do Brasil, Campinas, Editora Unicamp, 2006.

"Furtado: a questão regional e a agricultura itinerante" em WILSON CANO, Ensaios sobre a formação econômica regional do Brasil, Campinas, Universidade Estadual de Campinas, 2006.

Desconcentração produtiva regional do Brasil, 1970-2005, São Paulo, Universidade Estadual Paulista, 2007.

Desequilíbrios regionais e concentração industrial no Brasil, 1930-1970, São Paulo, Universidade Estadual Paulista, 2007.

Raízes da concentração industrial em São Paulo, Campinas, Universidade Estadual de Campinas, 2007.

"Reflexões sobre o papel do capital mercantil na questão regional e urbana do Brasil", Revista da Sociedade Brasileira de Economia Política, Sociedade Brasileira de Economia Politica, núm. 27, outubro, 2010.

A desindustrialização no Brasil, Campinas, Universidade Estadual de Campinas, 2012 (Texto para Discussão, núm. 200).

Carvalho, David Ferreira, Globalização financeira e Amazônia nos anos 90, Belém, Centro Sócio Econômico/Universidade Federal do Pará, 2006.

Centro Industrial do Brasil, O Brasil, suas riquezas naturais, suas indústrias, vol. 2 Indústria, Rio de Janeiro, s. e., 1908.

Empresa de Pesquisa Energética, Resenha mensal do consumo de energia elétrica, Brasília, Empresa de Pesquisa Energética, março, 2012. 
Fraga, Constantino C., "Resenha histórica do café no Brasil", Boletim da Divisão Económica Rural, Secretaria da Agricultura do estado de São Paulo, 1963.

FundaÇão Getúlio Vargas (FGV), Contas nacionais e regionais do Brasil, anos de 1939 a 1969.

Furtado, Celso, Formação econômica no Brasil, Rio de Janeiro, Editôra Fundo de Cultura, 1961.

Uma política de desenvolvimento econômico para o Nordeste, Recife, Ministério do Interior/Superintendência do Desenvolvimento do Nordeste, 1967.

Homma, Alfredo Kingo Oyama, A imigração japonesa na Amazônia: contribuição ao desenvolvimento agrícola, Belém, Embrapa Amazônia Oriental/Ministério da Agricultura, 2007.

Instituto Brasileiro de Geografia e Estatística, Censo industrial de 1985, Rio de Janeiro, 1986.

Censo agropecuário, Rio de Janeiro, Instituto Brasileiro de Geografia e Estatística, anos de 1995 e 2006.

Censo demográfico, Rio de Janeiro, Instituto Brasileiro de Geografia e Estatística, anos de 1970, 1980, 1991, 2000 e 2010.

Pesquisa industrial anual (PIA), Rio de Janeiro, Instituto Brasileiro de Geografia e Estatística, vários anos.

, Produção agrícola municipal, Rio de Janeiro, Instituto Brasileiro de Geografia e Estatística, vários anos.

Produção da extração vegetal e da silvicultura, Rio de Janeiro, Instituto Brasileiro de Geografia e Estatística, vários anos.

Produção da pecuária municipal, Rio de Janeiro, Instituto Brasileiro de Geografia e Estatística, vários anos.

Instituto Nacional de Pesquisas Espaciais, "Monitoramento do desmatamento por satélite", <http://www.obt.inpe.br/prodes/index.html>. [Dados coligidos em 25 de abril 2012.]

Lyra, Flávio Tavares, “Os Incentivos Fiscais à Indústria da Zona Franca de Manaus: Uma Avaliação”, Brasília, Instituto de Pesquisa Econômica Aplicada, relatório final, Texto para Discussão núm. 371, 1995.

Mahar, Dennis J., Desenvolvimento Econômico da Amazônia, Rio de Janeiro, Instituto de Pesquisa Econômica Aplicada, 1978.

Mendes, Armando Dias, "O anúncio de uma nova Amazônia” em J. M. Monteiro DA Costa (ed.), Amazônia: desenvolvimento e ocupação, Rio de Janeiro, Instituto de Pesquisa Econômica Aplicada, 1979.

Monteiro da Costa, J. M. (ed.), Amazônia: desenvolvimento e ocupação, Rio de Janeiro, Instituto de Pesquisa Econômica Aplicada, 1979.

"Amazônia: recursos naturais, tecnologia e desenvolvimento" em J. M. Monteiro da Costa (ed.), Amazônia: desenvolvimento e ocupação, Rio de Janeiro, Instituto de Pesquisa Econômica Aplicada, 1979. 
Monteiro dos Santos, Valdeci, "A economia do Sudeste Paraense: fronteira de expansão na periferia brasileira", tese de doutoramento, Campinas, Universidade Estadual de Campinas, 2011.

MotA, F. C. DE MACEDo. "Inserção externa e território: impactos do comércio exterior na dinâmica regional e urbana no Brasil (1989-2008)”, tese de livre docência, Campinas, Universidade Estadual de Campinas, 2010.

Pereira, Edgard A. e Ricardo Romano, Mercosul e as Zonas Francas, Zonas de Processamento de Exportações, Áreas de Livre Comércio e Áreas Aduaneiras Especiais, Brasília, Instituto de Pesquisa Econômica Aplicada, Texto para Discussão núm 283, 1992.

SAmpaio, Aldo Cesar Figueira, "O trabalho de Sísifo: crédito a comerciantes e reprodução do sistema de aviamento (1914-1919, 1943-1952)", Dissertação de estrado, Belém, Universidade Federal do Pará, 2002.

SANTOS, Roberto, "O equilíbrio da firma aviadora e a significação económico-institucional do aviamento", Pará Desenvolvimento, Instituto de Desenvolvimento Económico, Social e Produtivo, núm. 3, 1968, pp. 9-30.

História econômica da Amazônia, São Paulo, T. A. Queiroz, 1980.

Superintendência da Zona Franca de Manaus (Suframa), Indicadores de Desempenho do Pólo Industrial de Manaus, Ministério do Desenvolvimento, Indústria e Comércio Exterior, <http://www.suframa.gov.br/zfm_indicadores_do_pim.cfm>. [Dados coligidos em 24 de abril 2012.] 